\title{
Phytochemicals and The Ability of Plantago major Linn. Extract to Inhibit The growth of Aeromonas hydrophila
}

\author{
Annisa Farhana Dewi ${ }^{1 *}$, Arief Prajitno ${ }^{2}$, Ating Yuniarti ${ }^{2}$ \\ ${ }^{1}$ Master Program of Aquaculture, Faculty of Fisheries and Marine Science, University of Brawijaya, Malang, Indonesia \\ 2 Department of Aquaculture, Faculty of Fisheries and Marine Science, University of Brawijaya, Malang, Indonesia
}

\section{Abstract}

Aeromonas hydrophila is a type of gram-negative bacteria that can harm humans and major animals that have poikilotherm properties such as fish and shrimp. These bacteria can cause haemorrhages in fish until death and causing fish farming production to failure. The use of medicinal plants has been trusted by people all over the world to overcome various disease problems, one of which is a disease caused by bacteria. Plantago major L. is known that able to inhibit the growth of both gram-positive and gram-negative bacteria. The purposes of this study were to identify the extracted compounds contained in Plantago major L., using FTIR and UV-VIS spectrophotometer and to evaluate antibacterial activity against A. hydrophila. The results of this study showed that crude extracts of Plantago major $\mathrm{L}$. contained polar compounds such as phenols, flavonoids, saponins, and tannins. The presence of phenols, tanin and flavonoids was confirmed by the results of FTIR and UV-VIS. Furthermore, the crude extract of Plantago major L. significantly inhibited the growth of $A$. hydrophila $(P<0.05)$.

Keywords: Antibacterial, Co-culture, Extraction, FTIR, UV-VIS.

\section{INTRODUCTION*}

Aeromonas hydrophila is a type of bacteria that was widespread in both fresh and brackish water environments. These bacteria can infect various animals especially animals that are poikilotherm, such as fish and shrimp. If these animals are infected by the bacteria, the quality of their meats will be reduced [1,2,3]. $A$. hydrophila is known as an agent of Motile Aeromonas Disease or MAS, present as secondary pathogens in fish that have been exposed to environmental stress. The symptoms of MAS were observed as haemorrhages and pathological damages in internal organs. Infected fish experienced mortality up to $80-100 \%$ in a short time $[4,5,6]$.

The use of medicinal plants has been known and trusted by $80 \%$ of the World community. Plantago major $\mathrm{L}$. is a well-distributed plant over the World and known as a 'weed' that live freely in nature [7]. In Indonesia, $28 \%$ of Plantago major $\mathrm{L}$. is found growing wild on the roadside and used as a wound medicine [8]. It has an ability to cure white discharge problem [9], inflammation and coughing [10]. This weed was known to have several activities such as antibacterial, antifungal and antiviral agents as well as antioxidant and analgesic [11]. The previous study affirmed the benefits of Plantago

\footnotetext{
Correspondence Address:

Annisa Farhana Dewi

E-mail : annisafarhana3@gmail.com

Address : University of Brawijaya, Veteran Malang, 65145.
}

major L. in the field of health because of several compounds such as polyphenols, alkaloids, tannins, and steroids [12].

As an antibacterial agent, Plantago major $\mathrm{L}$. extract was able to inhibit gram-positive and gram-negative bacteria such as Lactobacillus sp., S. aureus, E. coli, P. aeruginosa, K. pneumonia, Proteus sp., S. enteriditis $[13,14]$. However, there is no report on the ability of Plantago major L. to inhibit the growth of A. hydrophila. Therefore the aim of this study was to determine the phytochemical content of Plantago major L. and its ability to inhibit the growth of A. hydrophila.

\section{MATERIAL AND METHODS \\ Phytochemical Extraction and Analysis}

The Phytochemical analysis was carried out by referring to the method of [15], to observe the content of phenols, flavonoids, alkaloids, tannins, saponin, terpenoids (steroids and triterpenoids). Plants of Plantago major L. aged 3-4 months were obtained from Materia Medica in Batu, dried for 5 days and made into powder using blender according to the method of [16], with modification. Plantago major L. powder (200 g) was macerated with $1 \mathrm{~L}$ of ethanol PA (1:5) for 5 days. The results of maceration were filtered using Whatman paper No. 42 and evaporated using a rotary vacuum evaporator at $50^{\circ} \mathrm{C}, 65$ rpm to obtain a thick green extract.

The extract was analysed using FTIR and UVVis spectrophotometry. FTIR is used to determine the functional group or type of the active compound based on the peak value of the 
wavelength. FTIR testing was conducted referring Jain et al. [17]. The obtained extract was mixed with $\mathrm{KBr}$ in a mortar and pressed with a pressure of 6 bars for 2 minutes. Samples were scanned on a spectrometer IR (FT 1000 Varian) 4000 - 400 $\mathrm{cm}^{-1}$.

UV-VIS analysis was carried out by using UVVisible spectrophotometry (Cary50 Conc Varian) [17]. Extract Plantago major L. was diluted using ethanol (1:10), then examined under UV wavelength $300-800 \mathrm{~nm}$.

\section{Antibacterial Test}

This research was carried out at the Fish Health and Disease Division Aquaculture Library, Faculty of Fisheries and Marine Science, Brawijaya University from November - December 2018. A bacterial isolate of A. hydrophila was obtained from BBPBAT Jepara, Central Java. The bacteria was rejuvenated with TSA medium and re-cultured in TSB medium with a bacterial density of $2.35 \times 10^{7} \mathrm{CFU} \cdot \mathrm{mL}^{-1}$. TSA medium that used for antibacterial activity was $20 \mathrm{ml}$ with spread method. Antibacterial activity tests were carried out using a disc diffusion method [18].

Blank disk with a size of $6 \mathrm{~mm}$ was dipped into the crude extract which has been diluted with $10 \%$ DMSO. The doses used were 100, 200, $300,400,500$ mg. $\mathrm{L}^{-1}$, with DMSO $10 \%$ as negative controls and Chloramphenicol as positive controls. All the treatments then incubated at the incubator $37^{\circ} \mathrm{C}$ for 24 hours. The diameter of the inhibition zone is measured using a caliper. Furthermore, co-culture tests were used to confirm the results of antibacterial activity by referring to the method [19] where bacterial culture and various concenterations of plant extracts were mixed in tubes containing sterile TSB medium, then incubated for 24 hours. The cultures were then transferred in TSA plates and bacterial density was enumerated after 24 hours.

\section{RESULT AND DISCUSSION FTIR Analysis}

The FTIR results of Plantago major L. and the absorption peaks are presented in Figure 1 and Table 1. From Figure 1, there are six types of absorption some of which are absorption at waves $3854.124 \mathrm{~cm}^{-1}$ indicating that there is an $\mathrm{O}-\mathrm{H}$ group, the changes in wave $3740.940 \mathrm{~cm}^{-1}$ detected the presence of $\mathrm{O}-\mathrm{H}$ groups, absorption at wave $3446.329 \mathrm{~cm}^{-1}$ shows the presence of O$\mathrm{H}$ groups with stretching vibrations, at wave $1640.934 \mathrm{~cm}^{-1}$ detected a $\mathrm{C}=\mathrm{C}$ group with stretch vibration, the strong absorption band at wave $1384.402 \mathrm{~cm}-1$ was found to be a $\mathrm{C}-\mathrm{H}$ group and the absorption of waves of $1050.935 \mathrm{~cm}^{-1}$ was found to have a $\mathrm{C}-\mathrm{O}$ bond with strong intensity. Stretch bands of phenyl groups $\mathrm{C}=\mathrm{C},-\mathrm{OH}$, and $\mathrm{CH}$ are characteristics of IR which indicate the presence of phenol and flavonoid and tannin compounds [20-23]. This absorption of the IR spectrum is similar to a previous study, which states that Plantago major L. contains a carboxyl, hydroxyl, and methyl group [24].

Tabel 1. FTIR Peak Result of Plantago major L.

\begin{tabular}{ccl}
\hline No. & Peak Values $\left(\mathbf{c m}^{-1}\right)$ & Functional Group \\
\hline 1. & 3854.124 & $\mathrm{O}-\mathrm{H}$ carboxylic acid \\
2. & 3740.940 & $\mathrm{O}-\mathrm{H}$ alcohol \\
3. & 3446.329 & $\mathrm{O}-\mathrm{H}$ alcohol, fenol \\
4. & 1640.934 & $\mathrm{C}=\mathrm{C}$ alkena \\
5. & 1384.402 & $\mathrm{C}-\mathrm{H}$ alkana \\
6. & 1050.935 & $\mathrm{C}-\mathrm{O}$ alcohol \\
\hline
\end{tabular}

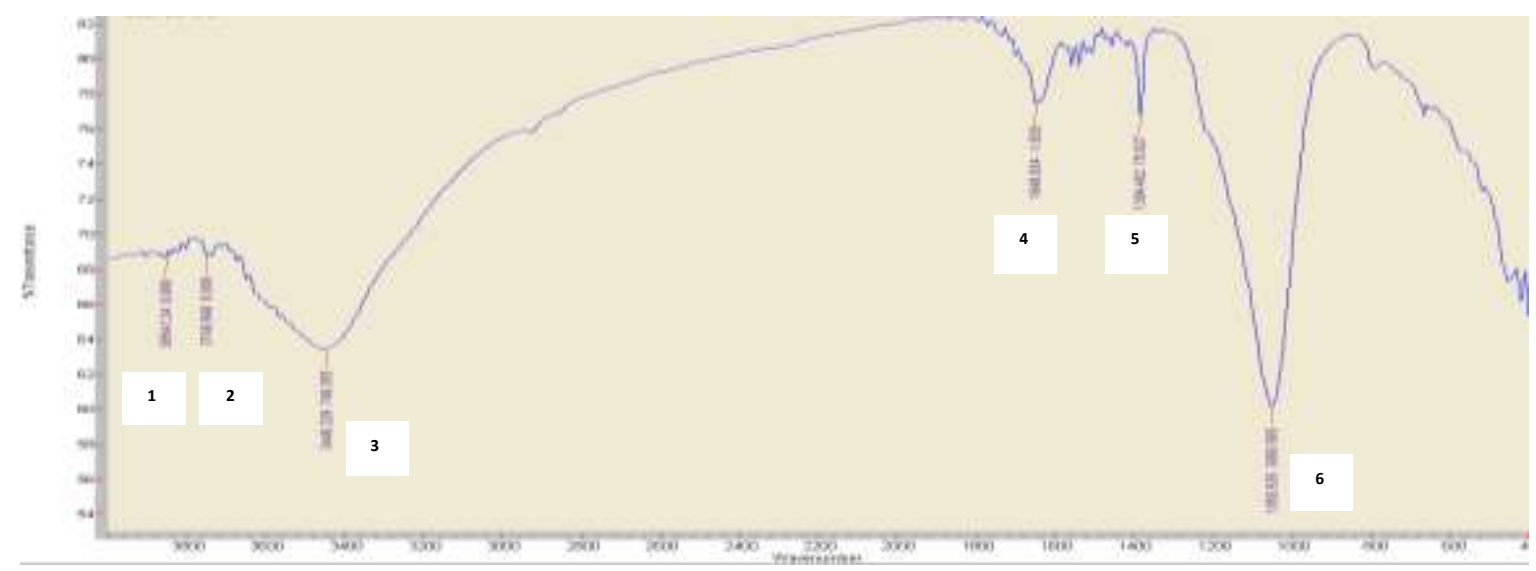

Figure 1. FTIR Test Results of Plantago major L. 


\section{UV-VIS Analysis}

UV-Vis results of Plantago major L. ethanol extract presented in (Fig. 2). The UV spectrum in the maximum wavelength at $227 \mathrm{~nm}, 411 \mathrm{~nm}$, and $505 \mathrm{~nm}$ strongly suspected contained phenol compounds that are flavonoids. The main flavonoids presents are flavones, flavonol, and auron. This was confirmed that flavones were the main type of flavonoids in Plantago major L. [25]. There are several flavones in Plantago major L. but only one flavonol was detected in UVspectophotometry [26].

\section{Phytochemical Extraction and Analysis}

Result of the phytochemical analysis showed that crude extract of Plantago major L. contained phenols, flavonoids, saponins, and tannins compounds. On the other hand, there were no alkaloid and terpenoid compounds (Table 2).
However, another study stated that Plantago major L. extract contained a composition of alkaloids and terpenoids [25]. Phenols, flavonoids, saponins, and tannins are polar compounds which have various functions, one of which is an antibacterial activity [27].

\begin{tabular}{llc}
\multicolumn{2}{c}{ Tabel 2. } & Phytochemical test result of Plantago major L. \\
\hline No. & Compound & Result \\
\hline 1. & Fenol & + \\
2. & Flavonoid & + \\
3. & Alkaloid & \\
& Mayer & - \\
& Dragendrof & - \\
& Bouchardat & - \\
4. & Saponin & + \\
5. & Tanin & + \\
6. & Terpenoid & - \\
& Steroid & - \\
\hline
\end{tabular}

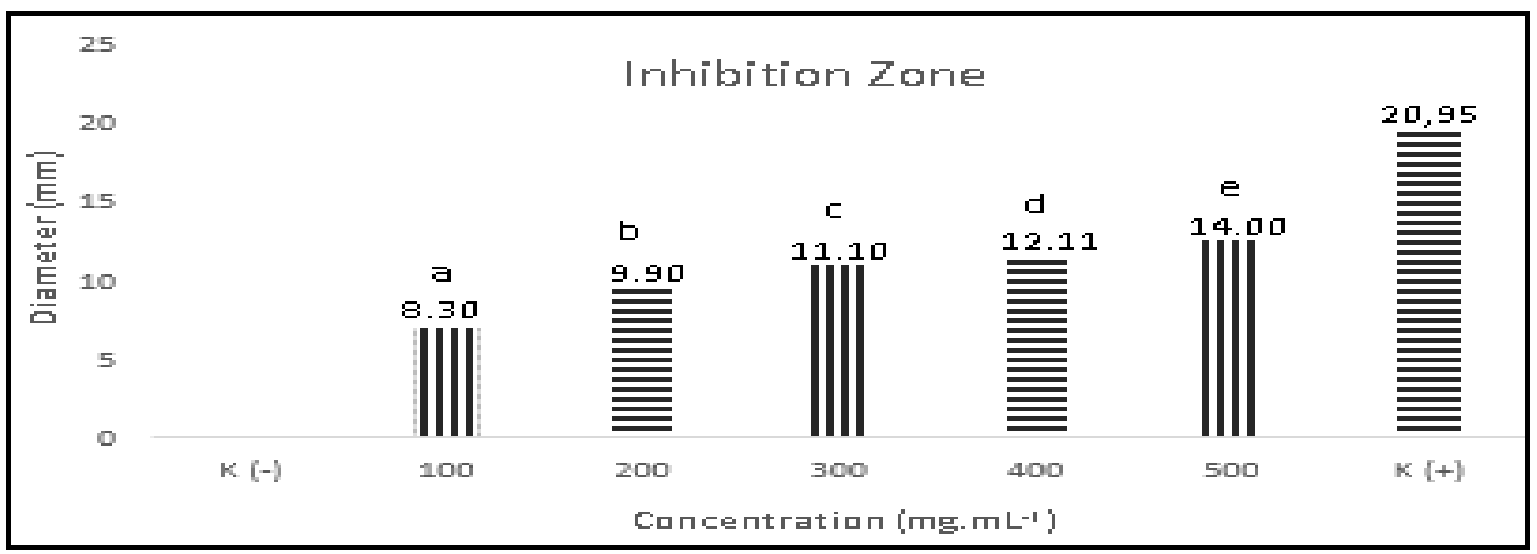

Figure 2. ntibacterial Test Results of Plantago major L.

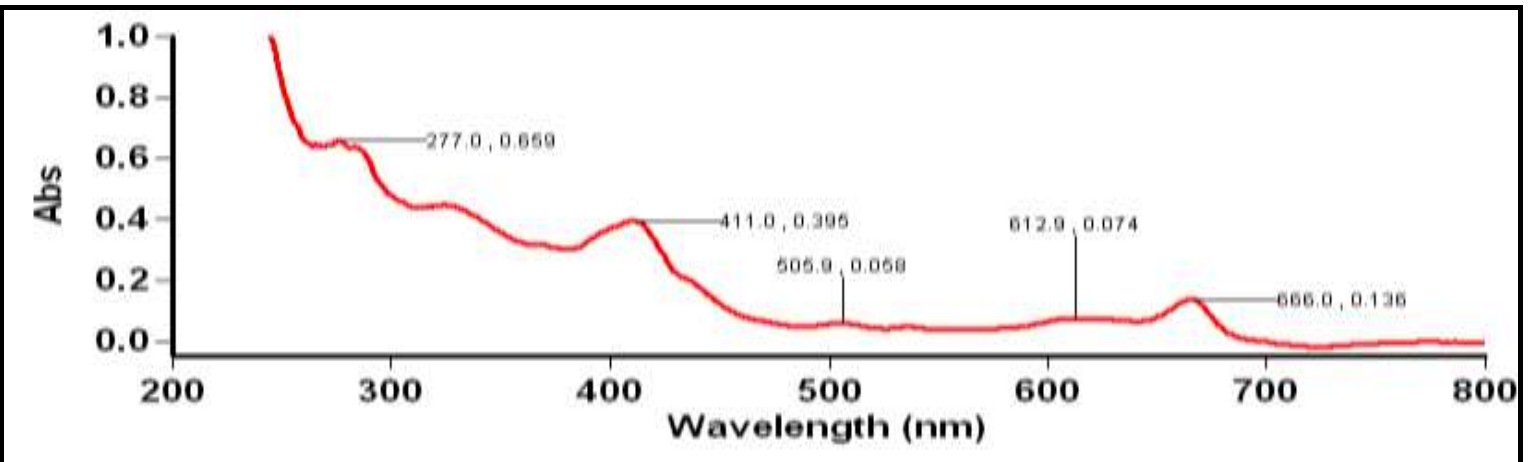

Figure 3. UV-VIS Test Result of Plantago major L.

\section{Antibacterial Activity}

The results of the antibacterial activity test showed that the crude extract of Plantago major L. had the ability to inhibit bacterial growth (Fig. 3 ). The inhibition of bacterial growth based on the extract dose. The higher dose, the greater diameter of the inhibition zone were formed. At the dose of 100 and $200 \mathrm{mg} \cdot \mathrm{L}^{-1}$, an inhibition zone is formed with medium strength, doses of 300,400 and $500 \mathrm{mg} \cdot \mathrm{L}^{-1}$ have a strong type of inhibition zone and the positive control using Chloramphenicol has a very strong inhibitory 
zone characteristic while the negative control using DMSO $10 \%$ does not create an inhibition zone. The provisions of the inhibitory level refer to Erlyn [28], the diameter of the inhibition zone $\geq 20 \mathrm{~mm}$ are included in the very strong category, $10-20 \mathrm{~mm}$ are included in the strong category, $10-5 \mathrm{~mm}$ has a medium category and $\leq 5 \mathrm{~mm}$ has a weak category.

The measurement results of the inhibition zone diameter were confirmed by the co-culture test presented in (Table 3). From the co-culture test explained that there was a decrease in the number of bacteria along with the larger dose given. This result strengthens the statement that Plantago major L. extract had the ability to inhibit the growth of A. hydrophila. Furthermore, Plantago major L. extract was able to significantly inhibit the growth of $A$. hydrophila $(P<0.05)$.

Table 3. Co-culture Test Result

\begin{tabular}{ccc}
\hline No. & Dosage (mg. $\left.\mathrm{L}^{-1}\right)$ & $\begin{array}{c}\text { Colony Forming Unit } \\
\text { (CFU.ml }\end{array}$ \\
\hline 1 & $\mathrm{C}(+)$ & 0 \\
2 & 100 & $2.10 \cdot 10^{13}$ \\
3 & 200 & $1.81 \cdot 10^{13}$ \\
4 & 300 & $1.23 \cdot 10^{11}$ \\
5 & 400 & $1.02 \cdot 10^{10}$ \\
6 & 500 & $8.6 \cdot 10^{9}$ \\
7 & $\mathrm{C}(-)$ & $3.65 \cdot 10^{18}$ \\
\hline
\end{tabular}

Based on phytochemical, FTIR and UV-VIS test results, Plantago major L. extract contain some compounds such as phenols, flavonoids, saponins and tannins which are capable to inhibit the growth of A. hydrophila. Phenol as antibacterial has a mechanism to inhibit bacterial growth by inactivating cell membrane proteins. Furthermore, phenol will bind to proteins in the structure of the bacterial cell wall to form hydrogen bonds [29]. Hydrogen bonds will make cell wall proteins and cytoplasmic membranes damaged so that there is an imbalance between the macromolecules and ions in the cell $[30,31]$.

Flavonoid as antibacterial work in various ways, including inhibition of DNA gyrase, inhibition of the cytoplasmic membrane and energy metabolism [32]. Flavonoids can damage the permeability of bacterial cell walls by binding to cell wall proteins so that bacterial growth will be inhibited [33]. The other flavonoid activity as an antibacterial is by binding to proteins so that it affects permeability, then it will enter into bacterial cells resulting in coagulation of proteins and causing inactivation of bacterial enzymes [34].

Saponin works by influencing the bacterial cell wall stress, this compound will bind to bacterial lipopolysaccharide which results in increased cell wall permeability and decreased surface tension of cell walls. Then saponin will enter the bacterial cell and disrupt the metabolism which causes the cell to lysis [36]. Tanin as an antibacterial will work by means of protein denaturation that prevents the metabolic process from being blocked. When the metabolic process is inhibited, growth and development of bacteria will be inhibited [36].

The antibacterial mechanism between one compound and another combined together will work synergistically and be more effective in fighting bacteria [37]. On the other hand, chloramphenicol was used as a positive control in this study because it is one of the antibiotics used to control the growth of A. hydrophila bacteria. Chloramphenicol is known to be able to inhibit the protein synthesis of $A$. hydrophila by binding to ribosome subunits so that peptide bond formation occurs [33,38].

\section{CONCLUSION}

Plantago major L. was known to have polar compounds such as phenol, flavonoid, saponin, and tannin. Phenol and flavonoid compounds contained in Plantago major L. are strengthened by wave detection from FTIR and UV-VIS results. Plantago major L. extract is known to have a significant effect on the inhibition of the growth of A. hydrophila bacteria significantly. In line with the result of this study, it can be suggested that further research on the antibacterial activity the plant extract with more solvent with a wider range of dosage.

\section{REFERENCES}

[1] Tahoun, A.B.M.B., H.A. Ahmed, R.M.M.A. Elez, A.A. El-Gedawy, I. Elsohaby, A.E.A. ElGhafar. 2016. Molecular characterisation, genotyping and survival of Aeromonas hydrophila isolated from milk, dairy products and humans in Egypt. Int. Dairy J. 63. 52-58.

[2] O'Ryan, M., Y.C. Lucero. 2018. Aeromonas Species. In: Principles and Practice of Pediatric Infectious Diseases, $5^{\text {th }}$ Ed. DOI: 10.1016/B978-0-323-40181-4.00150-X.

[3] Wiyanto, D.B. 2010. Antibacterial activities of seaweed grass extract Kappaphycus alvarezii and Eucheuma denticullatum against Aeromonas hydrophila and Vibrio harveyii bacteria. Mar. J. 3(1). 1-17. 
[4] Triyaningsih, Sarjito, S.B. Prayitno. 2014. Pathogenicity Aeromonas hydrophila isolated from catfish (Clarias Gariepinus) from Boyolali. J. Aquac. Manag. Tech. 3(2). 11-17.

[5] Peatman, E., H. Mohammed, A. Kirby, A. Craig, M. Yildirim-aksoy, B. H. Beck. 2017. Mechanisms of pathogen virulence and host susceptibility in virulent Aeromonas hydrophila infections of channel catfish (Ictalurus punctatus) Eric. Aquaculture. https://doi.org/10.1016/j.aquaculture.2017. 09.019 .

[6] Shahi, N., L. Ardó, G. Fazekas, E. Gócza, S. Kumar, N. Rèvèsz, ... G. Jeney. 2018. Immunogene expression in head kidney and spleen of common carp (Cyprinus carpio L .) following thermal stress and challenge with Gram-negative bacterium, Aeromonas hydrophila. Aquacult Int. 26 (1). 727 - 741.

[7] Haddadian, K., M. Zahmatkash. 2014. A review of Plantago plant. Indian J. Tradit. Knowl. 13. 681-685.

[8] Nahlunnisa, H., E.A.M. Zuhud, L.B. Prasetyo. 2015. Spatial distribution of food and medicinal plants diversity in Nyungcung Kampong, Malasari Village, Nanggung Subdistrict, Bogor. Media Conserv. 20(3). 187196.

[9] Yamin, M., Burhanudin, Jamaluddin, Nasruddin. 2018. Traditional treatment and medicines of Sasak Travel in Lombok. J. Trop. Biol. 18(1), 1-12.

[10] Kainde, A.R., D.H.C. Pangemanan, B.S.P. Hutagalung. 2016. Test the effectiveness of spoon leaf extract (Plantago major L.) on bleeding time in male Wistar rats (Rattus norvegicus). J. E-GiGi. 4(2). 271-276.

[11] Shirley, K.P., L.J. Windsor, G.J. Eckert, R.L. Gregory. 2015. In Vitro effects of Plantago major extract, aucubin, and baicalein on Candida Albicans biofilm formation, metabolic activity, and cell surface hydrophobicity. J. Prosthodont. 1-8.

[12] Karima, S., S. Farida, Z.M. Mihoub. 2015. Antioxidant and antimicrobial activities of Plantago major. J. Parm. Sci. 7(5). 58-64.

[13] Metiner, K., O. Ozkan, A. Seyyal. 2012. Antibacterial Effects of ethanol and acetone extract of Plantago major L. on Gram positive and gram negative bacteria Makale Kodu (Article Code ): KVFD-2011-5824 Gram Pozitif ve Gram Negatif Bakteriler üzerine
Plantago major L .' nin Etanol ve Aseton Ek. Kafkas Univ Vet Fak Derg. 18(3). 503-505.

[14] Razik, B.M.A., H.A. Hasan, M.K. Murtadha. 2012. The study of antibacterial activity of Plantago major and Ceratonia siliqua. Iraqi Postgrad. Med. J. 11(1). 130-135.

[15] Adhayanti, I., T. Abdullah, R. Romantika. 2018. Total Contents of polifenol and flavonoid ethyl asetic extract of the King's Skin (Musa paradisiaca Var. Sapientum. Pharm. Media. 14(1). 146-152.

[16] Putra, A.A.B., N.W. Bogoriani, N.P. Diantariani, L. Utari. 2014. Extraction of natural color of banana plant ball (Musa paradiasciaca L.) With maseration, refluks and socletas methods. Chem. J. 8(1). 113119.

[17] Jain, P.K., A. Soni, P. Jain, J. Bhawsar. 2016. Phytochemical analysis of Mentha spicata plant extract using UV-VIS, FTIR and GC/MS technique. J. Chem. Pharm. Res. 8, 1-6.

[18] Sambuaga, M.E., S.N.J. Longdong, H. Manoppo. 2018. Sensitivity of Ocimum sactum L extract on Aeromonas hydrophila. Budidaya Perairan. 6(1). 1-7.

[19] Aamer, A.A., M. Abdul-Hafeez, S. Sayed. 2015. Minimum Inhibitory and Bactericidal Concentrations (MIC and MBC) of Honey and bee propolis against Multi-Drug Resistant (MDR) Staphylococcus sp. Isolated from bovine clinical mastitis. Global J. Sci. Frontier Res. 3(4). DOI: 10.4172/23275162.1000171.

[20] Nugraha, A.C., A.T. Prasetya, S. Mursiti. 2017. Isolation, identification, Activity test of flavonoid compounds as antibacterials from mango leaves. Indonesian J. Chem. Sci. 6(2). 91-96.

[21] Kiswandono, A.A., E. Girsang, A.N. Pulungan, J.L. Sihombing, D. Siswanta, N.H. Aprilita, ... T. Hayashita. 2015. Kajian Spektra FTIR Pada Membran Kopoli (eugenol-divinilbenzena), Co-Edvb Sebagai Senyawa Pembawa Untuk Transpor Fenol. Proseding Seminar Nasional Pendidikan Sains. 543-554.

[22] Zirconia, A., N. Kurniasih, V. Amalia. 2015. Identification Of flavonoid compounds from kembang bulan leaves (Tithonia Diversifolia) Using shape action method. Kimiya. 2(1). 917.

[23] Juliani, N.D. Yuliana, S. Budijanto, C.H. Wijaya, A. Khatib. 2016. Analysis of aglucosidase and antioxidant inhibitors from 
kumis kucing with Metabolomic approach based on FTIR. J. Tech. Food Ind. 27(1). 1730.

[24] Behbahani, B.A.F., T. Yazdi, F. Shahidi, M.A. Hesarinejad, S.A. Mortazavi, M. Mohebbi. 2017. Plantago major seed mucilage: Optimization of extraction and some physicochemical and rheological aspects, Carbohydr. Polym. 155. 68-77.

[25] Adom, M.B., M. Taher, M.F. Mutalabisin, M.S. Amri, M.B.A. Kudos, M.W.A. Wan Sulaiman, ... D. Susanti. 2017. Chemical constituents and medical benefits of Plantago major. Biomed. Pharmacotherapy. 96. 348-360.

[26] Kawashty, S.A., E. Gamal-el-din, M.F. Abdalla, N.A.M. Saleh. 1994. Flavonoids of Plantago species in Egypt. Biochem. Syst. Ecol. 22(7). 729-733.

[27] Nugraha, A.C., A.T., Prasetya, S. Mursiti. 2017. Isolation, Identification, activity test of flavonoid compounds as antibacterials from mango leaves. Indonesian J. Chem. Sci. 6(2). 91-96.

[28] Erlyn, P. 2016. Effectiveness of Lemongrass active antibacterial (Cymbopogon citratus) on Streptococcus mutans bacteria introduction caries is a dental disease. Syifa MEDIKA. 6(2). 111-125.

[29] Novita, W. 2016. Antibacterial activities of sired leaf fraction (Piper betle L) on in vitro installation of Streptococcus mutans bacteria. JAMBI MEDICAL JOURNAL "Jurnal Kedokteran dan Kesehatan. 4. 140-155.

[30] Bontjura, S., O. A.Waworuntu, K.V. Siagian. 2015. Antibacterial effect of leilem leaf extract (Clerodendrum minahassae I.) on Streptococcus mutans bacteria. Pharmacon. 4(4). 96-101.

[31] Hariati, S., D. Wahjuningrum, M. Yuhana, K. Tarman, I. Effendi, F. Saputra. 2018. Aktivitas antibakteri ekstrak ketapang laut Nodulisporium Sp. Kt29 terhadap Vibrio harveyii. Jurnal Pengolahan Hasil Perikanan Indonesia. 21(2). 250-257.

[32] Suteja, I.K.P., W.S. Rita, I.W.G. Gunawan. 2016. Identification And test of activities of flavonoid compounds from trembesi leaf extract (Albizia saman (Jacq.) Merr) as an antibacteria of Escherichia coli. Chem. J. 10(1). 141-148.

[33] Putri, R.R., R. Hasanah, I. Kusimaningrum. 2016. Anti-bacterial Activity test and phytochemical test extract of mangrove leaves Sonneratia alba. J. Aquawarman. 2, 43-50.

[34] Nirwana, A.P., I.T. Susilowati. 2017. Antibacterial potency of Dendrophtoe petandra ethanol and ethyl asetat leaves extract against ESBL producting Klebsiella pneumoniae. Biomedika. 10(1). 36-41.

[35] Dwicahyani, T., Sumardianto, L. Rianingsih. 2018. Bioactivity test of sea cucumber Holothuria atra extracts as antibacterial agent for Staphylococcus aureus and Escherichia coli Tiara. J. Peng \& Biotech. 7(1). 15-24.

[36] Karmila, U., S. Karina, C. Yulvizar. 2017. Tumeric Curcuma domestica extract As anti bacteria for Aeromonas hydrophila in fish patin Pangasius sp. Mar. Fish. Sci. J. Unsyiah. 2(1). 150-157.

[37] Rempe, C.S., K.P. Burris, S.C. Lenaghan, C. N. Stewart. 2017. The potential of systems biology to discover antibacterial mechanisms of plant phenolics. Front. Microbiol. 8. 422. DOI: 10.3389/fmicb.2017. 00422.

[38] Dian, R., Fatimawali, B. Fona. 2015. Test resistance of Escherichia coli bacteria isolated from dental plakes to mercury and antibiotics cloramfenicol. Biomedik. 3. 5963. 